\title{
A Review on Plant Responses to Soil Salinity and Amelioration Strategies
}

\author{
Mohammad Golam Kibria*, Md. Anamul Hoque \\ Department of Soil Science, Bangladesh Agricultural University, Mymensingh, Bangladesh \\ Email: *kibria.ss@bau.edu.bd
}

How to cite this paper: Kibria, M.G. and Hoque, Md.A. (2019) A Review on Plant Responses to Soil Salinity and Amelioration Strategies. Open Journal of Soil Science, 9 , 219-231.

https://doi.org/10.4236/ojss.2019.911013

Received: October 7, 2019

Accepted: October 29, 2019

Published: November 1, 2019

Copyright $\odot 2019$ by author(s) and Scientific Research Publishing Inc. This work is licensed under the Creative Commons Attribution International License (CC BY 4.0).

http://creativecommons.org/licenses/by/4.0/

(c) (i) Open Access

\begin{abstract}
Soil salinity is a major abiotic stress, limiting plant growth and development worldwide. Plants grown under saline soil condition experiences a significant amount of high osmotic stress, ion toxicities and nutritional disorder, and these are responsible for poor soil physical condition as well as lead to reduced plant productivity. Plants exhibit a number of responses under salt stress by affecting morphological, physiological and biochemical process. A complete understanding of how plants respond to soil salinity and comprehensive management approaches of combining physiological and biochemical attributes with molecular tools are essential for mitigating the adverse effects of salinity on plant growth and productivity. Recent reports on the plant responses due to soil salinity highlighted the importance of integration of different advanced strategies to address the problem of soil salinity. This review will focus on morphological and physiological changes of plants under saline soil and an overview of suitable strategies to regulate plant adaptation and tolerance to salinity stress.
\end{abstract}

\section{Keywords}

Salinity, Antioxidant Enzymes, Adaptation To Salinity, Proline, Plant Physiology

\section{Introduction}

Saline soil is one of the major environmental threats that limit plant growth due to high salt concentration and the process of increasing salt content is known as salinization [1]. Soil salinization is a global land degradation issue [2] and mostly affects the coastal areas by developing soil salinity. Approximately $7 \%$ of the total world's land, $20 \%$ of the world's cultivated land and nearly half of the irrigated land are affected by soil salinity [1]. Furthermore, the salt-affected areas are increasing annually by $10 \%$ each year and if the problem is not addressed 
now, more than $50 \%$ of the arable land would be salinized by the year 2050 [3].

Soil salinity imposes a significant number of negative impacts on plants growth and productivity. Reduced plant growth and productivity may result from an unbalanced supply of photosynthetic assimilates or hormones to the growing tissues [4]. In addition, ionic toxicity in saline soil can also contribute to limiting plant growth due to the replacement of $\mathrm{K}^{+}$by $\mathrm{Na}^{+}$in biochemical reactions, and $\mathrm{Na}^{+}$and $\mathrm{Cl}^{-}$induced conformational changes in proteins [5]. Ionic toxicities may also cause metabolic imbalance and protein synthesis [6]. The adverse effects of salinity on plant development are more profound during the reproductive phase and lead to cell cycle imbalance and differentiation. Hence, the adverse effects of salinity may be attributed to the salt-stress effect on the cell cycle and differentiation. Salt tress restricts cell cycle transiently by interfering with cyclins and kinase activities within the plant system, and thereby results in fewer cells in the meristem, thus limiting growth [1]. Salt stress may also affect plant growth by interfering in seed germination, enzymatic activity and unbalancing mitosis [7].

Soil salinity is a prevalent abiotic stress that alters geographical distribution of plants. The impact of salinity is most serious in countries where all or most of agricultural production is based on irrigation [8]. As irrigated agriculture expands, more salinity problems will develop because there are millions of hectares of potentially irrigable land that could become saline. A lot of research has been conducted on this issue and it is found that it has many detrimental effects on plant growth and development [9]. There are many factors that influence plant responses to salinity by affecting plant growth and production. The effects of osmotic stress can also be observed in different physiological and biochemical parameters of plants. Researchers have identified a number of plant responses due to soil salinity and also recommended different approaches to address the problem. But there is a lack of coordination between the plants physiological as well as biochemical responses with a possible selection of management strategies. Therefore, the objective of this review is to explore the effects of salinity on plant growth and how management practices can prevent soil and water salinization and mitigate the adverse effects of salinity. The design of framework has been presented in Figure 1.

\section{How Plants Respond to Soil Salinity?}

Plants show differential responses to salinity which is efficiently expressed into physiological attributes adopting or alleviating the shock from salt stress [10]. Figure 2 represents the whole plant responses under salt stress.

The earliest response of plants exposed to elevated soil salinity level is the slow growth rate of leaves. Under low soil salinity level, root growth is almost always less affected than shoot growth, so the root: shoot ratio increases [11], but root growth also decreases when they are exposed to higher soil salinity level [12] [13]. Plant experiences a significant decrease in dry biomass accumulation due to decrease in shoot and root growth under elevated salt-stressed condition [14]. 


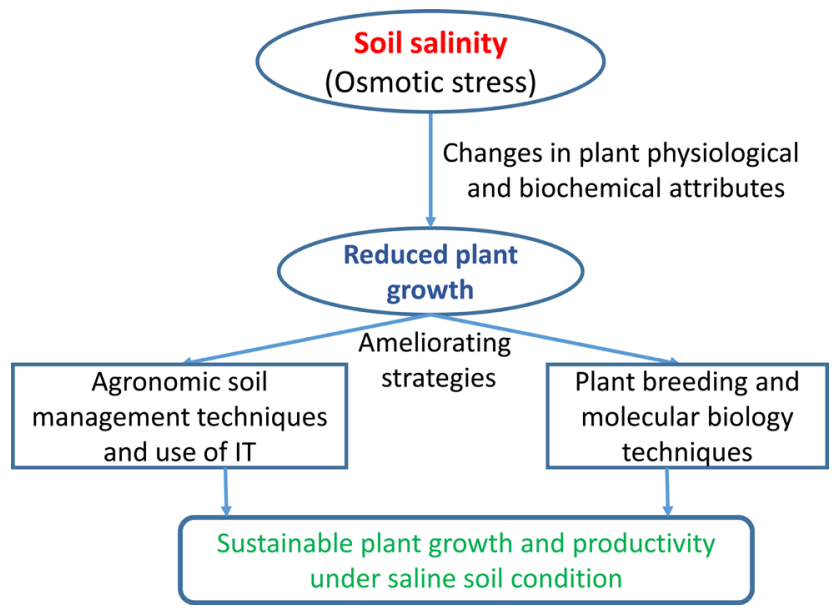

Figure 1. Design of framework for this review (Source: authors).

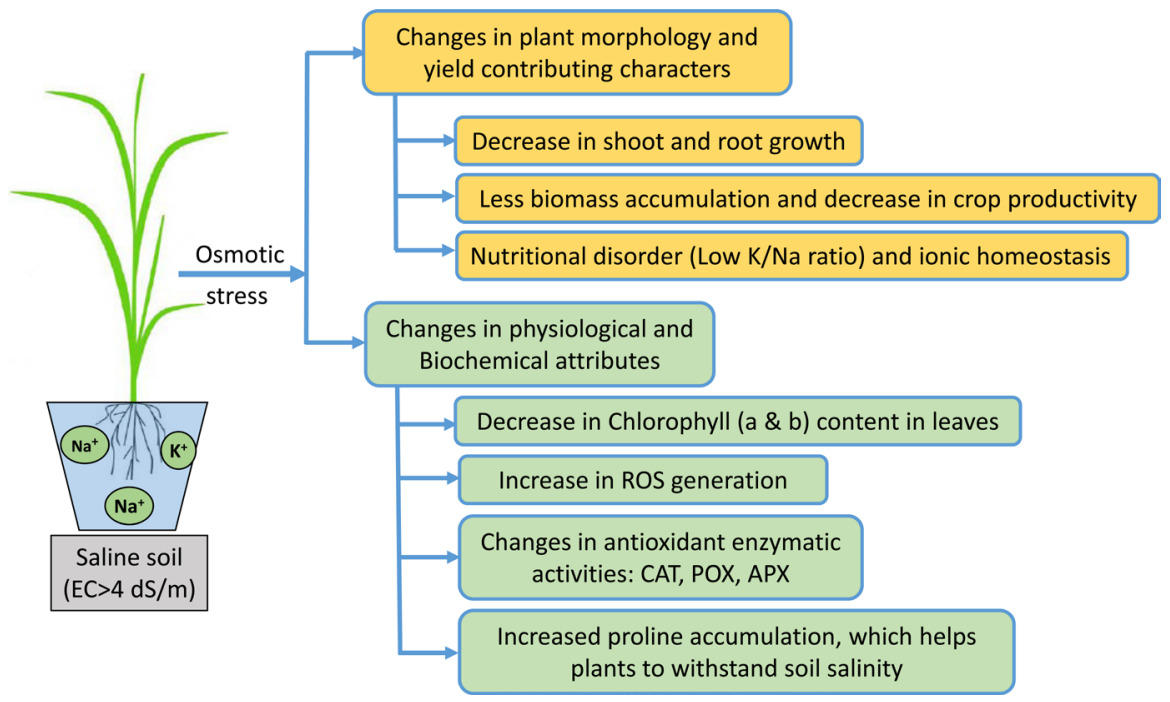

Figure 2. Plant responses subjected to salt stress (Source: authors).

Decreasing rates of new cell production may cause the inhibition of growth as reported by Shabala, Babourina and Newman [15]. The reduction in dry weight accumulation could be attributed to increasing stiffness of the cell wall due to altered cell wall structure induced by salinity. Salt stress in the root zone causes the development of osmotic stress, which disrupts cell ion homeostasis by inducing both the inhibition in uptake of essential nutrients such as $\mathrm{K}^{+}$and increased accumulation of $\mathrm{Na}^{+}$and $\mathrm{Cl}^{-}$[16]. Higher uptake of $\mathrm{Na}^{+}$competes with the uptake of other nutrient ions, especially $\mathrm{K}^{+}$, and causes $\mathrm{K}^{+}$deficiency which leads to lower $\mathrm{K}^{+} / \mathrm{Na}^{+}$ratio in plants under salt stress [10]. Salt-stressed plants also show significant changes in physiological and biochemical parameters of plants such as lower level of leaf chlorophyll content, decrease in protein synthesis, increased ROS accumulation, enhanced accumulation of compatible solutes such as proline, changes in antioxidant enzymatic activities. Thus all the morphological, physiological and biochemical changes of plants exposed to salt stress are combinedly responsible for overall changes in plant growth and productivity. 


\section{Effects of Salinity on Physiological and Biochemical Attributes of Plants}

Salinity stress involves changes in various biochemical and metabolic processes, depending on severity and duration of the stress, and ultimately inhibits crop growth and productivity. Excessive soluble salt concentrations affect biochemical attributes of plants by increasing the osmotic potential of the soil solution as well as specific ion toxicities in soil. Different biochemical attributes like chlorophyll content and intercellular proline accumulation are greatly influenced under salt stress.

\subsection{Leaf Chlorophyll Contents under Salt Stress}

Chlorophyll is the most important component in the photosynthesis process and the rate of photosynthesis depends on the level of chlorophyll content in plant leaves. The decline in productivity has been observed in many plant species subjected to salt stress is often associated with a reduction in leaf photosynthetic capacity [10] [17]. Decrease in leaf chlorophyll content is the first visible symptom of plants subjected to salt stress [14]. Changes in leaf chlorophyll content vary depending on the level of salt tolerance of plants and salt-tolerant genotypes showed less loss of chlorophyll than relatively sensitive genotypes [8]. Plant experiences lower chlorophyll content in plant leaves probably due to inhibition of chlorophyll pigment formation through the accumulation of $\mathrm{Na}^{+}$under salt stress [18] or cell membrane deterioration [19]. Usually there is dominance of chlorophyll-a over chlorophyll-b in plants but their values become closer with the increasing salinity level [20]. The decrease in leaf chlorophyll contents (a \& b) of salt-stressed plants is a result of either slow synthesis or fast breakdown, indicated that there was a photoprotection mechanism through reducing light absorbance by decreasing chlorophyll contents [21].

\subsection{Compatible Solute Accumulation and Osmotic Protection}

Compatible solutes are the group of chemically diverse organic compounds generated in plants and they do not interfere with the cellular metabolism even at high concentration [2]. These compatible solutes include amino acid proline [22], glycinebetaine [23], sugar [24], etc. As the accumulation of these compounds is proportional to the external osmolarity, they protect cellular structures by maintaining osmotic balance within the cell via continuous water influx [25]. Accumulation of compatible solutes is one of the adaptive mechanisms of plants to withstand salt stress [26]. Enhanced salt stress causes a significant decrease in number of amino acids such as cysteine, arginine, and methionine (around 55\% of total free amino acids in plant), but proline, proteinogenic amino acid concentration increases [27]. Proline accumulation under abiotic stress occurs in taxonomically diverse sets of plants [28], and increased proline accumulation in plants is correlated with enhanced salt tolerance [29]. Increased proline accumulation in plants under salt stress showed higher salt tolerance in a 
number of plant species such as rice [10], barley [30], pea [17] and soybean [31]. Therefore, it is evident that leaf proline index shows a strong positive relationship with plant yield potential [32] and is thus a promising index for deploying in breeding programs for evolving salt tolerant cultivars [33].

Glycinebetaine, a nontoxic cellular osmolyte, raises the osmolarity of plant cell during stress period [2] and protects cells by osmotic adjustment, protein stabilization [34] and scavenging reactive oxygen species (ROS) in plants [26]. When rice plants are exposed to enhanced salt stress, accumulated glycinebetaine positively protects the ultrastructure of seedlings [35]. Even foliar application of this amino acid showed a positive correlation with plant growth under salt stress by stabilizing photosynthetic pigments and scavenging ROS [36]. Other than amino acids, accumulation of carbohydrates such as sugar and starch is a common feature of salt-stressed plants [37]. The accumulated carbohydrates in plants under salt stress play important roles in stress mitigation involves osmoprotection, carbon storage, and scavenging of reactive oxygen species [2]. Salt stress increases the level of reducing sugars (sucrose and fructans) in plants and protects plants from osmotic damages by abiotic stresses such as soil salinity.

\subsection{Increased ROS Accumulation in Plants under Salt Stress}

One of the biochemical changes occurring when plants are subjected to biotic or abiotic stresses is the production of reactive oxygen species [38]. Reactive oxygen species (ROS) are highly reactive and in the absence of any protective mechanism they can seriously disrupt normal metabolism through oxidative damage to lipids, protein and nucleic acids [39]. In salt-stressed plants, molecular oxygen $\left(\mathrm{O}_{2}\right)$ acts as an electron acceptor, giving rise to the accumulation of ROS [2]. Reactive oxygen species include singlet oxygen, hydroxyl radical $\left(\mathrm{OH}^{-}\right)$, superoxide radical, and hydrogen peroxide $\left(\mathrm{H}_{2} \mathrm{O}_{2}\right)$ are all strongly oxidizing compounds and therefore potentially harmful for cell integrity [40].

As cell membranes are the first targets of many plant stresses, reactive oxygen species (ROS) may destroy normal metabolism through peroxidation of membrane lipids [39]. Lipid peroxidation of biological membranes might lead to structural alterations such as denaturalization of proteins and nucleic acids in salt-stressed plants. Experimental evidences suggest that lipid peroxidation reaction of cellular membranes may play an important role in radical mediated cell injury [41]. Therefore, activity of antioxidant enzymes may act as efficient determinant criteria in the toxicity degree to salt stressed plants. Crucial changes in soil salinity can lead to osmotic stress, which are primary effects of salt stress. Such free radicals and other active derivatives of oxygen may produce inevitably as by-products of physiological redox reactions. It has been reported that when ROS exceeded the capacity of scavenging system of plants [42], it results in oxidative damage [17]. The increased levels of ROS can inactivate enzymes, damage important cellular components, which induced plant growth arrest, and even death finally [39]. 


\subsection{Changes in Antioxidant Enzymatic Activities (CAT, POX, APX) of Plants}

To mitigate the deleterious effects of salinity on regular metabolism, plants have evolved various strategies to contend with this problem [38]. Plants possess an array of enzymatic and non-enzymatic antioxidant defense systems to protect their cells against the damaging effects of ROS [43]. Superoxide dismutase (SOD) is a major scavenger of superoxide and its enzymatic action results in the formation of $\mathrm{H}_{2} \mathrm{O}_{2}$ and $\mathrm{O}_{2}$ [44]. The hydrogen peroxide produced is then scavenged by different antioxidant enzymes including catalase (CAT), a variety of peroxidase such as guaiacol peroxidase (POX) and ascorbate peroxidase (APX). Catalase converts $\mathrm{H}_{2} \mathrm{O}_{2}$ into water and molecular oxygen [45], whereas peroxidase decomposes $\mathrm{H}_{2} \mathrm{O}_{2}$ by oxidation of co-substrates such as phenolic compounds or antioxidants [46]. These antioxidant enzymes show differential responses varying in the level of salt tolerance.

Generally, plants exhibit an increase in CAT activity with the increasing magnitude of $\mathrm{NaCl}$ concentration in soil [47], but this increased accumulation is not similar for all the plant genotypes. Plants show differential responses on CAT activity under salt stress depending on their levels of salt tolerance. For example, in salt-sensitive soybean genotypes, CAT activity decreases with increasing salt stress [48]. But increased CAT activity was observed in salt-tolerant soybean genotypes [31]. A linear and significant increase in CAT activity is observed in response to increased salt concentration after exposure to salt stress in barley [30] and green bean [49]. Among the root crops, potato is comparatively more salt-tolerant and also exhibits a significant increase in CAT activity with the increasing salinity level [50]. Pea plants are normally sensitive to salt stress and CAT activity shows a declining trend with increasing the magnitude of $\mathrm{NaCl}$ stress accordingly [17]. From the research findings on different crops, it can be assumed that CAT activities were higher in the salt-tolerant one than the salt-sensitive cultivar and this increase in CAT activity helps plant to mitigate osmotic stress due to soil salinity [10].

Among the peroxidase enzymes, guaiacol peroxidase (POX) is considered as one of the most important enzymes for protecting plants from the oxidative damage of ROS [51]. Salt stress significantly increases the activity of antioxidant enzyme i.e. peroxidase (POX) in case of salt-sensitive rice varieties but tolerant varieties exhibit the declining trends of activity of POX enzyme activity with the increasing salt concentration [22]. In case of soybean, POX activity increases as a result of increasing salt concentration [31]. Salt stress significantly increases the POX activities in potato [50] and pea [17], which may help plants to mitigate osmotic damages by ROS. Other than POX, ascorbate peroxidase (APX) enzyme helps to protect plants from osmotic stress by neutralizing the ROS, evident in rice [22] and soybean [31]. Over expression of the APX gene in plants has been reported to improve protection against oxidative stress. APX activities increased with increasing salt stress in both salt-sensitive and salt-tolerant varieties and the 
activities were higher in the salt-tolerant one than the salt-sensitive cultivar [49]. These enzymes (CAT, POX and APX) were also reported to be important in salt tolerance mechanisms in some other crops such as mulberry [52], cotton [53] and maize [51].

\subsection{Changes in Potassium (K) and Sodium (Na) Ratio of Plants}

Salinity imposes both ionic toxicity and osmotic stress to plants [25], leading to nutritional disorder [54]. In saline soil, the concentration and availability of $\mathrm{Na}^{+}$ are comparatively higher than the concentration of $\mathrm{K}^{+}$in soil solution [55]. Salt stress disturbs cytoplasmic $\mathrm{K}^{+} / \mathrm{Na}^{+}$homeostasis, causing an increase in $\mathrm{Na}^{+}$to $\mathrm{K}^{+}$ ratio in the cytosol [56]. Salt tolerance is directly associated with $\mathrm{K}^{+}$contents because of its involvement in osmotic regulation and competition with $\mathrm{Na}^{+}$. Salt tolerance mechanism of plants requires not only the adaptation to $\mathrm{Na}^{+}$toxicity but also the acquisition of abundant $\mathrm{K}^{+}$whose uptake by the plant cell is affected by high external $\mathrm{Na}^{+}$concentrations [57].

The salt-sensitive and salt-tolerant plants show differential responses in the aspect of $\mathrm{K}^{+} / \mathrm{Na}^{+}$ratio in both root and shoot under salt stress [58]. The tolerant genotypes can control the uptake of $\mathrm{Na}^{+}$, resulting in a higher $\mathrm{K}^{+} / \mathrm{Na}^{+}$ratio with greater dry biomass accumulation, which helps to dilute the absorbed $\mathrm{Na}^{+}$within plant system. Whereas, the sensitive genotypes had higher $\mathrm{Na}^{+}$and lower $\mathrm{K}^{+}$ contents, resulting in lower $\mathrm{K}^{+} / \mathrm{Na}^{+}$ratio in plants [59]. There is a significant negative correlation between leaf $\mathrm{Na}^{+}$and $\mathrm{K}^{+} / \mathrm{Na}^{+}$ratio in different rice varieties differing in salt tolerance under salt stress [60]. Other than rice, soybean also experiences decrease in $\mathrm{K}^{+} / \mathrm{Na}^{+}$ratio with the increasing salinity level [48]. Root crops like potato also show the decrease in $\mathrm{K}^{+} / \mathrm{Na}^{+}$ratio under salt stress [50]. This decrease in $\mathrm{K}^{+} / \mathrm{Na}^{+}$ratio under salt stress causes $\mathrm{Na}^{+}$toxicity in plants and leads to cellular damage and deficiency in potassium in plant, which ultimately decreases crop growth and productivity.

\section{Approaches to Mitigate the Adverse Effects of Soil Salinity on Crop Production}

Worldwide, extensive research is being carried out, to develop strategies to cope with abiotic stresses, through development of salt-tolerant cultivars, shifting the crop calendars, resource management practices, etc. Possible soil salinity amelioration strategies are summarized in Table 1 with few references.

Among the soil salinity management strategies, use of salt-tolerant plant genotypes showed better performance compared to others. Advanced plant breeding and molecular biology techniques suggest to use salt-tolerant genotypes with effective management strategies to mitigate the adverse effects of soil salinity. In alignment with this, exogenous application of compatible solutes shows significant increase in growth and productivity. Regulation of gene expression in salinity stress includes a wide array of mechanisms that are used by plants to up-regulate or down-regulate the production of specific gene to mitigate the adverse effect of 
Table 1. Strategies to mitigate soil salinity problem.

\begin{tabular}{|c|c|c|}
\hline Serial no. & Strategies or management practices & References \\
\hline 1 & Development and use of salt-tolerant genotypes & $\begin{array}{l}\text { Kumar, Beena, Awana and Singh [9] } \\
\text { Kibria, Hossain, Murata and Hoque [10] }\end{array}$ \\
\hline 2 & $\begin{array}{l}\text { Exogenous application of compatible solutes such as } \\
\text { proline, glycine-betaine }\end{array}$ & $\begin{array}{l}\text { Sabagh, Sorour, Ragab, Saneoka and Islam [61] } \\
\text { Okuma, Murakami, Shimoishi, Tada and Murata [29] }\end{array}$ \\
\hline 3 & $\begin{array}{l}\text { Use of fresh water as a safe source of irrigation for } \\
\text { agricultural purposes in coastal belt }\end{array}$ & Panagea, Daliakopoulos, Tsanis and Schwilch [62] \\
\hline 4 & Organic amendment with proper $\mathrm{K}$ and $\mathrm{Zn}$ fertilization & $\begin{array}{l}\text { Kibria, Farhad and Hoque [63] } \\
\text { Rady [64] }\end{array}$ \\
\hline 5 & $\begin{array}{l}\text { Hormone regulation to improve the antioxidant defense } \\
\text { mechanism of plants }\end{array}$ & $\begin{array}{l}\text { Caverzan, Casassola and Brammer [65] } \\
\text { Kim, Mun, Khan, Waqas, Kim, Shahzad, Imran, Yun and Lee [66] }\end{array}$ \\
\hline 6 & Use of plant growth-promoting bacteria (PGPB) & $\begin{array}{l}\text { Shrivastava and Kumar [1] } \\
\text { Numan, Bashir, Khan, Mumtaz, Shinwari, Khan, Khan and Al-Harrasi [67] }\end{array}$ \\
\hline 7 & Remote sensing and GIS in salinity mapping & Asfaw, Suryabhagavan and Argaw [68] \\
\hline 8 & $\begin{array}{l}\text { Genetic engineering, modifying gene expression and } \\
\text { transcriptional regulation }\end{array}$ & Gupta and Huang [2] \\
\hline
\end{tabular}

soil salinity. Transcriptomic analysis provides detailed knowledge to screen candidate genes involved in stress responses. This is the baseline to start with molecular approaches to develop salt-tolerant genotypes from indigenous species. Recently, use of plant growth-promoting bacteria (e.g. Pseudomonas) and rhizospheric bacteria showed a positive relationship with plant growth and productivity under salt stress. Furthermore, saline soil survey through advanced technologies such as GIS may help to plan accordingly based on salinity level in a specific area. Soil salinity management includes a complex interaction between all the management strategies and no parameter can ameliorate this problem solely. Therefore, it is essential to interact with all the management strategies to mitigate the adverse effects of soil salinity on crop production.

\section{Conclusion and Recommendation}

Soil salinity is prevalent abiotic stress that limits plant growth and productivity. Salinity tolerance mechanism of plants requires a complex interaction of genetic, cellular, metabolic and physiological responses. However, a lack of coordination of plant physiological and molecular responses is essential for sustainable and effective plant salinity tolerance. This review has highlighted that no single parameter could be suggested as sole possible way for salinity stress tolerance plants. A combination of all suitable management strategies can contribute to salt tolerance of plants. The future focus should be on the study of intercellular and intracellular molecular interaction involved in salinity stress responses.

\section{Conflicts of Interest}

The authors declare no conflicts of interest regarding the publication of this paper. 


\section{References}

[1] Shrivastava, P. and Kumar, R. (2015) Soil Salinity: A Serious Environmental Issue and Plant Growth Promoting Bacteria as One of the Tools for Its Alleviation. Saudi Journal of Biological Sciences, 22, 123-131. https://doi.org/10.1016/j.sjbs.2014.12.001

[2] Gupta, B. and Huang, B. (2014) Mechanism of Salinity Tolerance in Plants: Physiological, Biochemical, and Molecular Characterization. International Journal of Genomics, 2014, Article ID: 701596. https://doi.org/10.1155/2014/701596

[3] Jamil, A., Riaz, S., Ashraf, M. and Foolad, M.R. (2011) Gene Expression Profiling of Plants under Salt Stress. Critical Reviews in Plant Sciences, 30, 435-458. https://doi.org/10.1080/07352689.2011.605739

[4] Shahbaz, M. and Ashraf, M. (2013) Improving Salinity Tolerance in Cereals. Critical Reviews in Plant Sciences, 32, 237-249. https://doi.org/10.1080/07352689.2013.758544

[5] Assaha, D.V.M., Ueda, A., Saneoka, H., Al-Yahyai, R. and Yaish, M.W. (2017) The Role of $\mathrm{Na}(+)$ and $\mathrm{K}(+)$ Transporters in Salt Stress Adaptation in Glycophytes. Frontiers in Physiology, 8, 509. https://doi.org/10.3389/fphys.2017.00509

[6] Zhu, J.K. (2002) Salt and Drought Stress Signal Transduction in Plants. Annual Review of Plant Biology, 53, 247-273.

https://doi.org/10.1146/annurev.arplant.53.091401.143329

[7] Panuccio, M.R., Jacobsen, S.E., Akhtar, S.S. and Muscolo, A. (2014) Effect of Saline Water on Seed Germination and Early Seedling Growth of the Halophyte Quinoa. AoB Plants, 6, plu047. https://doi.org/10.1093/aobpla/plu047

[8] Ghosh, N., Adak, M.K., Ghosh, P.D., Gupta, S., Sen Gupta, D.N. and Mandal, C. (2011) Differential Responses of Two Rice Varieties to Salt Stress. Plant Biotechnology Reports, 5, 89-103. https://doi.org/10.1007/s11816-010-0163-y

[9] Kumar, S., Beena, A.S., Awana, M. and Singh, A. (2017) Physiological, Biochemical, Epigenetic and Molecular Analyses of Wheat (Triticum aestivum) Genotypes with Contrasting Salt Tolerance. Frontiers in Plant Science, 8, 1151. https://doi.org/10.3389/fpls.2017.01151

[10] Kibria, M.G., Hossain, M.A., Murata, Y. and Hoque, M.A. (2017) Antioxidant Defense Mechanisms of Salinity Tolerance in Rice Genotypes. Rice Science, 24, 155-162. https://doi.org/10.1016/j.rsci.2017.05.001

[11] Munnus, R. and Termaat, A. (1986) Whole-Plant Responses to Salinity. Australian Journal of Plant Physiology, 13, 143-160. https://doi.org/10.1071/PP9860143

[12] Koca, H., Bor, M., Ozdemir, F. and Turkan, I. (2007) The Effect of Salt Stress on Lipid Peroxidation, Antioxidative Enzymes and Proline Content of Sesame Cultivars. Environmental and Experimental Botany, 60, 344-351. https://doi.org/10.1016/j.envexpbot.2006.12.005

[13] Tuna, A.L., Kaya, C., Dikilitas, M. and Higgs, D. (2008) The Combined Effects of Gibberellic Acid and Salinity on Some Antioxidant Enzyme Activities, Plant Growth Parameters and Nutritional Status in Maize Plants. Environmental and EXperimental Botany, 62, 1-9. https://doi.org/10.1016/j.envexpbot.2007.06.007

[14] Amirjani, M.R. (2011) Effects of Salinity Stress on Growth, Sugar Content, Pigments and Enzyme Activity of Rice. International Journal of Botany, 7, 73-81. https://doi.org/10.3923/ijb.2011.73.81

[15] Shabala, S., Babourina, O. and Newman, I. (2000) Ion-Specific Mechanisms of Osmoregulation in Bean Mesophyll Cells. Journal of Experimental Botany, 51, 
1243-1253. https://doi.org/10.1093/jexbot/51.348.1243

[16] Paranychianakis, N.V. and Chartzoulakis, K.S. (2005) Irrigation of Mediterranean Crops with Saline Water: From Physiology to Management Practices. Agriculture, Ecosystems \& Environment, 106, 171-187. https://doi.org/10.1016/j.agee.2004.10.006

[17] Ozturk, L., Demir, Y., Unlukara, A., Karatas, I., Kurunc, A. and Duzdemir, O. (2012) Effects of Long-Term Salt Stress on Antioxidant System, Chlorophyll and Proline Contents in Pea Leaves. Romanian Biotechnological Letters, 17, 7227-7236.

[18] Carter, D.L. and Myers, V.I. (1963) Light Reflectance and Chlorophyll and Carotene Contents of Grape Fruit Leaves as Affected by $\mathrm{Na}_{2} \mathrm{SO}_{4}, \mathrm{NaCl}$ and $\mathrm{CaCl}_{2}$. Proceedings of the American Society for Horticultural Science, 82, 217-221.

[19] Tantawy, A.S., Abdel-Mawgoud, A.M.R., ElNemr, M.A. and Chamoun, Y.G. (2009) Alleviation of Salinity Effects on Tomato Plants by Application of Amino Acids and Growth Regulators. European Journal of Science Research, 30, 848-894.

[20] Mane, A.V., Karadge, B.A. and Samant, J.S. (2010) Salinity Induced Changes in Photosynthetic Pigments and Polyphenols of Cymbopogon nardus (L.) Rendle. Journal of Chemical and Pharmaceutical Research, 2, 338-347.

[21] Elsheery, N.I. and Cao, K.F. (2008) Gas Exchange, Chlorophyll Fluorescence, and Osmotic Adjustment in Two Mango Cultivars under Drought Stress. Acta Physiologiae Plantarum, 30, 769-777. https://doi.org/10.1007/s11738-008-0179-x

[22] Nounjan, N., Nghia, P.T. and Theerakulpisut, P. (2012) Exogenous Proline and Trehalose Promote Recovery of Rice Seedlings from Salt-Stress and Differentially Modulate Antioxidant Enzymes and Expression of Related Genes. Journal of Plant Physiology, 169, 596-604. https://doi.org/10.1016/j.jplph.2012.01.004

[23] Wang, Y. and Nii, N. (2000) Changes in Chlorophyll, Ribulose Bisphosphate Carboxylase-Oxygenase, Glycine Betaine Content, Photosynthesis and Transpiration in Amaranthus Tricolor Leaves during Salt Stress. Journal of Horticultural Science and Biotechnology, 75, 623-627. https://doi.org/10.1080/14620316.2000.11511297

[24] Kerepesi, I. and Galiba, G. (2000) Osmotic and Salt Stress-Induced Alteration in Soluble Carbohydrate Content in Wheat Seedlings. Crop Science, 40, 482-487. https://doi.org/10.2135/cropsci2000.402482x

[25] Hasegawa, P.M., Bressan, R.A., Zhu, J.K. and Bohnert, H.J. (2000) Plant Cellular and Molecular Responses to High Salinity. Annual Review of Plant Physiology and Plant Molecular Biology, 51, 463-499. https://doi.org/10.1146/annurev.arplant.51.1.463

[26] Ashraf, M. and Foolad, M.R. (2007) Roles of Glycinebetaine and Proline in Improving Plant Abiotic Stress Tolerance. Environmental Experiment of Botany, 59, 206-216. https://doi.org/10.1016/j.envexpbot.2005.12.006

[27] El-Shintinawy, F. and El-Shourbagy, M.N. (2001) Alleviation of Changes in Protein Metabolism in NaCl-Stressed Wheat Seedlings by Thiamine. Biologia Plantarum, 44, 541-545. https://doi.org/10.1023/A:1013738603020

[28] Saxena, S.C., Kaur, H., Verma, P., Petla, B.P. andugula, V.R. and Majee, M. (2013) Osmoprotectants: Potential for Crop Improvement under Adverse Conditions. In: Tuteja, N. and Singh, S.G., Eds., Plant Acclimation to Environmental Stress, Springer, New York, 197-232. https://doi.org/10.1007/978-1-4614-5001-6_9

[29] Okuma, E., Murakami, Y., Shimoishi, Y., Tada, M. and Murata, Y. (2004) Effects of Exogenous Application of Proline and Betaine on the Growth of Tobacco Cultured Cells under Saline Conditions. Soil Science and Plant Nutrition, 50, 1301-1305. https://doi.org/10.1080/00380768.2004.10408608 
[30] Reza, S., Heidari, R., Zare, S. and Norastehnia, A. (2006) Antioxidant Response of Two Salt Stressed Barley Varieties in the Presence or Absence of Exogenous Proline. General and Applied Plant Physiology, 32, 233-251.

[31] Weisany, W., Sohrabi, Y., Heidari, G., Siosemardeh, A. and Ghassemi-Golezani, K. (2012) Changes in Antioxidant Enzymes Activity and Plant Performance by Salinity Stress and Zinc Application in Soybean (Glycine max L.). Plant Omics, 5, 60-67.

[32] Verbruggen, N. and Hermans, C. (2008) Proline Accumulation in Plants: A Review. Amino Acids, 35, 753-759. https://doi.org/10.1007/s00726-008-0061-6

[33] Summart, J., Thanonkeo, P., Panichajakul, S., Prathepha, P. and McManus, M.T. (2010) Effect of Salt Stress on Growth, Inorganic Ion and Proline Accumulation in Thai Aromatic Rice, Khao Dawk Mali 105, Callus Culture. African Journal of Biotechnology, 9, 145-152.

[34] Rani, A. and Venkatesu, P. (2018) Changing Relations between Proteins and Osmolytes: A Choice of Nature. Physical Chemistry Chemical Physics, 20, 20315-20333. https://doi.org/10.1039/C8CP02949K

[35] Rahman, S., Miyake, H. and Takeoka, Y. (2002) Effects of Exogenous Glycinebetaine on Growth and Ultrastructure of Salt-Stressed Rice Seedlings (Oryza sativa L.). Plant Production Science, 5, 33-44. https://doi.org/10.1626/pps.5.33

[36] Cha-Um, S. and Kirdmanee, C. (2010) Effect of Glycinebetaine on Proline, Water Use, and Photosynthetic Efficiencies, and Growth of Rice Seedlings under Salt Stress. Turkish Journal of Agriculture and Forestry, 34, 517-527.

[37] Parida, A.K., Das, A.B. and Mohanty, P. (2004) Investigations on the Antioxidative Defence Responses to $\mathrm{NaCl}$ Stress in a Mangrove, Bruguiera parviflora: Differential Regulations of Isoforms of Some Antioxidative Enzymes. Plant Growth Regulation, 42, 213-226. https://doi.org/10.1023/B:GROW.0000026508.63288.39

[38] Apel, K. and Hirt, H. (2004) Reactive Oxygen Species: Metabolism, Oxidative Stress, and Signal Transduction. Annual Review of Plant Biology, 55, 373-399. https://doi.org/10.1146/annurev.arplant.55.031903.141701

[39] Arora, A., Sairam, R.K. and Srivastava, G.C. (2002) Oxidative Stress and Antioxidative Systems in Plants. Current Science, 82, 1227-1238.

[40] Santos, A.L., Sinha, S. and Lindner, A.B. (2018) The Good, the Bad, and the Ugly of ROS: New Insights on Aging and Aging-Related Diseases from Eukaryotic and Prokaryotic Model Organisms. Oxidative Medicine and Cellular Longevity, 2018, Article ID: 1941285. https://doi.org/10.1155/2018/1941285

[41] Zhang, L.X., Li, S.X., Zhang, H. and Liang, Z.S. (2007) Nitrogen Rates and Water Stress Effects on Production, Lipid Peroxidation and Antioxidative Enzyme Activities in Two Maize (Zea mays L.) Genotypes. Journal of Agronomy and Crop Science, 193, 387-397. https://doi.org/10.1111/j.1439-037X.2007.00276.X

[42] Caverzan, A., Piasecki, C., Chavarria, G., Stewart, C.N. and Vargas, L. (2019) Defenses against ROS in Crops and Weeds: The Effects of Interference and Herbicides. International Journal of Molecular Sciences, 20, 1086. https://doi.org/10.3390/ijms20051086

[43] Mishra, S. and Das, A.B. (2003) Effect of $\mathrm{NaCl}$ on Leaf Salt Secretion and Antioxidative Enzyme Level in Roots of a Mangrove, Aegiceras corniculatum. Indian Journal of Experimental Biology, 41, 160-166.

[44] Kim, S.Y., Lim, J.H., Park, M.R., Kim, Y.J., Park, T.I.I. and Seo, Y.W. (2005) Enhanced Antioxidant Enzymes Are Associated with Reduced Hydrogen Peroxide in Barley Roots under Salt Stress. Journal of Biochemistry and Molecular Biology, 38, 218-224. https://doi.org/10.5483/BMBRep.2005.38.2.218 
[45] Mittova, V., Guy, M., Tal, M. and Volokita, M. (2004) Salinity Up-Regulates the Antioxidative System in Root Mitochondria and Peroxisomes of the Wild Salt-Tolerant Tomato Species Lycopersicon pennellii. Journal of Experimental Botany, 55, 1105-1113. https://doi.org/10.1093/jxb/erh113

[46] Khedr, A.H.A., Abbas, M.A., Wahid, A.A.A., Quick, W.P. and Abogadallah, G.M. (2003) Proline Induces the Expression of Salt-Stress-Responsive Proteins and May Improve the Adaptation of Pancratium maritimum L. to Salt-Stress. Journal of EXperimental Botany, 54, 2553-2562. https://doi.org/10.1093/jxb/erg277

[47] Nounjan, N. and Theerakulpisut, P. (2012) Effects of Exogenous Proline and Trehalose on Physiological Responses in Rice Seedlings during Salt-Stress and after Recovery. Plant, Soil and Environment, 58, 309-315. https://doi.org/10.17221/762/2011-PSE

[48] Dogan, M. (2011) Antioxidative and Proline Potentials as a Protective Mechanism in Soybean Plants under Salinity Stress. African Journal of Biotechnology, 10, 5972-5977.

[49] Yasar, F., Ellialtioglu, S. and Yildiz, K. (2008) Effect of Salt Stress on Antioxidant Defense Systems, Lipid Peroxidation, and Chlorophyll Content in Green Bean. Russian Journal of Plant Physiology, 55, 782-786. https://doi.org/10.1134/S1021443708060071

[50] Daneshmand, F., Arvin, M.J. and Kalantari, K.M. (2009) Effect of Acetyl Salicylic Acid (Aspirin) on Salt and Osmotic Stress Tolerance in Solanum bulbocastanum in Vitro: Enzymatic Antioxidants. American-Eurasian Journal of Agricultural and Environmental Science, 6, 92-99.

[51] Neto, A.D.D., Prisco, J.T., Eneas, J., de Abreu, C.E.B. and Gomes, E. (2006) Effect of Salt Stress on Antioxidative Enzymes and Lipid Peroxidation in Leaves and Roots of Salt-Tolerant and Salt-Sensitive Maize Genotypes. Environmental and Experimental Botany, 56, 87-94. https://doi.org/10.1016/j.envexpbot.2005.01.008

[52] Sudhakar, C., Lakshmi, A. and Giridarakumar, S. (2001) Changes in the Antioxidant Enzyme Efficacy in Two High Yielding Genotypes of Mulberry (Morus alba L.) under $\mathrm{NaCl}$ Salinity. Plant Science, 161, 613-619. https://doi.org/10.1016/S0168-9452(01)00450-2

[53] Meloni, D.A., Oliva, M.A., Martinez, C.A. and Cambraia, J. (2003) Photosynthesis and Activity of Superoxide Dismutase, Peroxidase and Glutathione Reductase in Cotton under Salt Stress. Environmental and Experimental Botany, 49, 69-76. https://doi.org/10.1016/S0098-8472(02)00058-8

[54] Zhu, J.K. (2003) Regulation of Ion Homeostasis under Salt Stress. Current Opinion in Plant Biology, 6, 441-445. https://doi.org/10.1016/S1369-5266(03)00085-2

[55] Tavakkoli, E., Rengasamy, P. and McDonald, G.K. (2010) High Concentrations of $\mathrm{Na}^{+}$and $\mathrm{Cl}^{-}$Ions in Soil Solution Have Simultaneous Detrimental Effects on Growth of Faba Bean under Salinity Stress. Journal of Experimental Botany, 61, 4449-4459. https://doi.org/10.1093/jxb/erq251

[56] Gul, M., Wakeel, A., Steffens, D. and Lindberg, S. (2019) Potassium-Induced Decrease in Cytosolic $\mathrm{Na}(+)$ Alleviates Deleterious Effects of Salt Stress on Wheat ( Triticum aestivum L.). Plant Biology, 21, 825-831. https://doi.org/10.1111/plb.12999

[57] Zhang, J.L., Flowers, T.J. and Wang, S.M. (2010) Mechanisms of Sodium Uptake by Roots of Higher Plants. Plant and Soil, 326, 45-60. https://doi.org/10.1007/s11104-009-0076-0

[58] Zheng, Y.H., Li, X., Li, Y.G., Miao, B.H., Xu, H., Simmons, M. and Yang, X.H. 
(2012) Contrasting Responses of Salinity-Stressed Salt-Tolerant and Intolerant Winter Wheat (Triticum aestivum L.) Cultivars to Ozone Pollution. Plant Physiology and Biochemistry, 52, 169-178. https://doi.org/10.1016/j.plaphy.2012.01.007

[59] Nakhoda, B., Leung, H.T., Mendioro, M., Nejad, G.M. and Ismail, A.M. (2012) Isolation, Characterization, and Field Evaluation of Rice (Oryza sativa L., Var. IR64) Mutants with Altered Responses to Salt Stress. Field Crops Research, 127, 191-202. https://doi.org/10.1016/j.fcr.2011.11.004

[60] Ul Haq, T., Akhtar, J., Nawaz, S. and Ahmad, R. (2009) Morpho-Physiological Response of Rice (Oryza sativa L.) Varieties to Salinity Stress. Pakistan Journal of Botany, 41, 2943-2956.

[61] Sabagh, A.E., Sorour, S., Ragab, A., Saneoka, H. and Islam, M.S. (2017) The Effect of Exogenous Application of Proline and Glycine Betaine on the Noduleactivity of Soybean under Saline Condition. Journal of Agricultural Biotechnology, 2, 1-5.

[62] Panagea, I.S., Daliakopoulos, I.N., Tsanis, I.K. and Schwilch, G. (2016) Evaluation of Promising Technologies for Soil Salinity Amelioration in Timpaki (Crete): A Participatory Approach. Solid Earth, 7, 177-190. https://doi.org/10.5194/se-7-177-2016

[63] Kibria, M.G., Farhad and Hoque, M.A. (2015) Alleviation of Soil Salinity in Rice by Potassium and Zinc Fertilization. International Journal of Experimental Agriculture, 5, 15-21.

[64] Rady, M.M. (2012) A Novel Organo-Mineral Fertilizer Can Mitigate Salinity Stress Effects for Tomato Production on Reclaimed Saline Soil. South African Journal of Botany, 81, 8-14. https://doi.org/10.1016/j.sajb.2012.03.013

[65] Caverzan, A., Casassola, A. and Brammer, S.P. (2016) Antioxidant Responses of Wheat Plants under Stress. Genetics and Molecular Biology, 39, 1-6. https://doi.org/10.1590/1678-4685-GMB-2015-0109

[66] Kim, Y., Mun, B.G., Khan, A.L., Waqas, M., Kim, H.H., Shahzad, R., Imran, M., Yun, B.W. and Lee, I.J. (2018) Regulation of Reactive Oxygen and Nitrogen Species by Salicylic Acid in Rice Plants under Salinity Stress Conditions. PLoS ONE, 13, e0192650. https://doi.org/10.1371/journal.pone.0192650

[67] Numan, M., Bashir, S., Khan, Y., Mumtaz, R., Shinwari, Z.K., Khan, A.L., Khan, A. and Al-Harrasi, A. (2018) Plant Growth Promoting Bacteria as an Alternative Strategy for Salt Tolerance in Plants: A Review. Microbiological Research, 209, 21-32. https://doi.org/10.1016/j.micres.2018.02.003

[68] Asfaw, E., Suryabhagavan, K.V. and Argaw, M. (2018) Soil Salinity Modeling and Mapping Using Remote Sensing and GIS: The Case of Wonji Sugar Cane Irrigation Farm, Ethiopia. Journal of the Saudi Society of Agricultural Sciences, 17, 250-258. https://doi.org/10.1016/j.jssas.2016.05.003 